\title{
Rheological control on the dynamics of explosive activity in the 2000 summit eruption of Mt. Etna
}

\author{
D. Giordano ${ }^{1}$, M. Polacci ${ }^{2}$, P. Papale ${ }^{2}$, and L. Caricchi ${ }^{3, *}$ \\ ${ }^{1}$ Institut de Ciències de la Terra Jaume Almera (ICTJA), CSIC, c/Lluís Solé Sabarís s/n, 08028 Barcelona, Spain \\ ${ }^{2}$ Istituto Nazionale di Geofisica e Vulcanologia, Sezione di Pisa, Via della Faggiola 32, 56126 Pisa, Italy \\ ${ }^{3}$ Institut des Sciences de la Terre d'Orleans, UMR 6113 CNRS - Universite d'Orleans, 1A rue de la Ferollerie, \\ 45071 Orleans Cedex, France \\ *now at: Department of Earth Sciences, University of Bristol, Queens Road, Bristol, BS8 1RJ, UK
}

Received: 28 December 2009 - Published in Solid Earth Discuss.: 19 February 2010

Revised: 25 May 2010 - Accepted: 21 June 2010 - Published: 1 July 2010

\begin{abstract}
In the period from January to June 2000 Mt. Etna exhibited an exceptional explosive activity characterized by a succession of 64 Strombolian and fire-fountaining episodes from the summit South-East Crater. Textural analysis of the eruptive products reveals that the magma associated with the Strombolian phases had a much larger crystal content $(>55$ vol\%) with respect to the magma discharged during the firefountain phases $(\sim 35 \mathrm{vol} \%)$. Rheological modelling shows that the crystal-rich magma falls in a region beyond a critical crystal content where small addition of solid particles causes an exponential increase of the effective magma viscosity. When implemented into the modeling of steady magma ascent dynamics (as assumed for the fire-fountain activity), a large crystal content as the one found for products of Strombolian eruption phases results in a one order of magnitude decrease of mass flow-rate, and in the onset of conditions where small heterogeneities in the solid fraction carried by the magma translate into highly unsteady eruption dynamics. We argue that crystallization on top of the magmatic column during the intermediate phases when magma was not discharged favoured conditions corresponding to Strombolian activity, with fire-fountain activity resuming after removal of the highly crystalline top. The numerical simulations also provide a consistent interpretation of the association between fire-fountain activity and emergence of lava flows from the crater flanks.
\end{abstract}

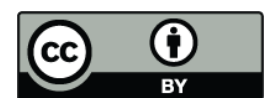

Correspondence to: D. Giordano (dgiordano@ija.csic.es)

\section{Introduction}

Persistently active basaltic volcanoes, such as Mt. Etna, Italy, display different styles of volcanic activity including effusion of lava, fire-fountains and Strombolian explosions. Plinianlike explosive eruptions are rarer events, but they have been also documented (e.g., Coltelli et al., 2000; Branca and Del Carlo, 2004). Because of its hazard implications, basaltic explosive activity is increasingly better monitored (as an example, see the Istituto Nazionale di Geofisica e Vulcanologia, sezione di Catania, website at www.ct.ingv.it) and studied (among the others, Taddeucci et al., 2004; Allard et al., 2005; Ripepe et al., 2005; Burton et al., 2007; Gurioli et al., 2008; Pioli et al.; 2008) by the international scientific community. At Mt. Etna, the most common explosive activity spans from mild to moderate Strombolian explosions to violent fire-fountain episodes consisting of vigorous, continuously sustained jets of magma and gas, often accompanied by ash emissions. A spectacular example of this type of activity is represented by the 64 fire-fountain episodes occurred at the South-East crater on the summit of Mt. Etna between January and June 2000 (Alparone et al., 2003) (Fig. 1). Characterization of selected products erupted from this paroxysmal activity demonstrated substantial textural and compositional variations relating to the dominant style (either Strombolian or fire-fountain) of the eruption (Polacci et al., 2006).

Despite compositions and textures are known to control the rheological behaviour of magmas (e.g., Lejeune and Richet, 1995; Pinkerton and Stevenson, 1996; Giordano et al., 2009) a few studies have investigated the rheological

Published by Copernicus Publications on behalf of the European Geosciences Union. 


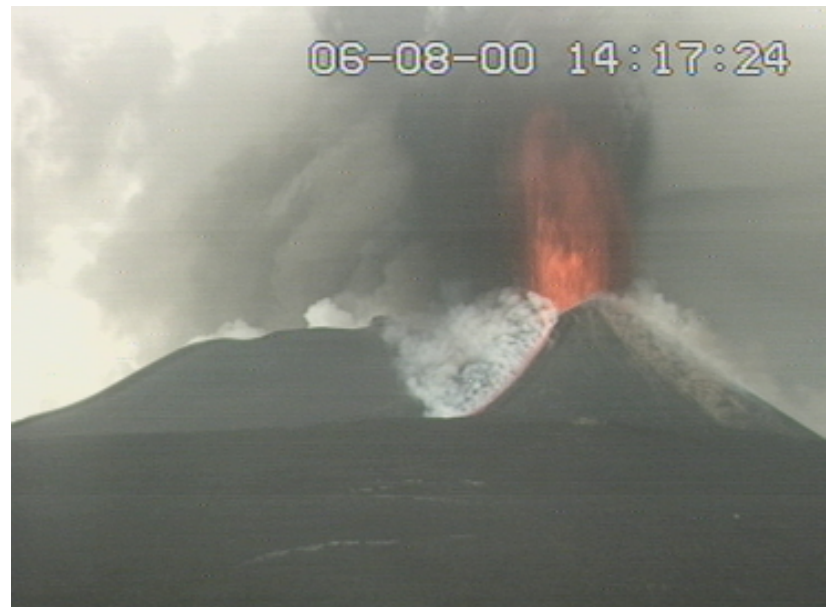

Fig. 1. Fire-fountain activity at the South-East crater of Mt. Etna on 8 June 2000. Horizontal edge of photo $\sim 700 \mathrm{~m}$. Courtesy of D. Andronico.

properties of specific basaltic liquids (Giordano and Dingwell, 2003) and basaltic magmas at subliquidus conditions (Shaw, 1969; Ryerson, 1988; Pinkerton and Norton, 1995; Sato, 2005; Giordano et al., 2007; Ishibashi and Sato, 2007; Ishibashi, 2009). However, none of the previous studies allows tracking of the rheological variation associated with crystallization, vesiculation, cooling and straining of a basaltic magma during its rise to the surface. Only recently, the accessibility to modern high temperature, high pressure deformational facilities has allowed Earth scientists to build numerical and experimental predictive models accounting for the evolution of the rheological properties of magmas as they change in the volcanic conduit during magma rise to the surface.

In order to quantify the effect of rheology on Mt. Etna eruptive style, in this study we combine two empirical models that allow us to account for the variation of silicate melt viscosity in the $T$ (temperature)- $\mathrm{X}$ (composition) $-\mathrm{H}_{2} \mathrm{O}$ space (Giordano et al., 2008) and for the non-Newtonian rheological effects due to the presence of crystals in strained magmas (Costa et al., 2009). These models are applied to calculate the viscosity of volcanic products discharged during selected eruptive episodes of the January-June 2000 Mt. Etna explosive activity. In the following we show that non-Newtonian effects due to straining of crystal-bearing magmas result in substantial differences in the apparent viscosities for the magmas erupted during the Strombolian and fire-fountain phases. The textural and compositional changes observed in scoria clasts erupted during the two different eruptive phases (i.e. Strombolian or fire-fountain) of the 2000 eruption are related to pronounced and relatively sharp changes in rheology. Such changes were initiated by a difference in the crystal content of the erupted magmas, and coincided with a change of the style of eruptions and a shift from Strombolian to firefountain activity. A better understanding of the rheology of
Etnean magmas and its correlation with the eruptive style provides constraints to models of the dynamics of explosive activity at this volcano, including sudden shifts between eruptive styles that are common at basaltic volcanoes. Ultimately, a thorough comprehension of the rheological properties of magma systems is a valuable tool for improving monitoring and hazard forecasting of active volcanoes.

\section{The January-June 2000 Mt. Etna eruption: summary of activity and features of the erupted products}

In this study we investigate the evolution of the rheological properties characterizing volcanic products erupted at Mt. Etna during the first semester of 2000 . We choose to study this period of activity for the following reasons: first, it represents the most remarkable cyclic explosive activity over a short period of time in the known history of the volcano; second, it allows us to constrain the transition from Strombolian to fire-fountain activity by a rheological point of view; and third, an accurate description of this activity exists in terms of geophysical and geochemical signals (Alparone et al., 2003; Allard et al., 2005), offering a substantial dataset to our rheological modelling.

\subsection{Eruption chronology and styles of activity}

The eruptive period considered in this study started on 26 January 2000, ended on 24 June of the same year and focussed at the South-East Crater, generating 64 paroxysms each consisting of an initial Strombolian phase that was gradually replaced by a phase of sustained fire-fountain activity. The former activity, usually lasting from a few to tens of minutes, consisted of mild to moderate to increasingly stronger explosions of gas and fragmented magma particles (ash, lapilli and bombs); the latter also coincided with the peak of the tremor signal and lasted from tens of minutes to a few hours, consisting of continuous, violent, hundredsof-metres-high jets of magma and gas that lead to the formation of ash plumes up to a height of $6 \mathrm{~km}$ above the crater. Fire-fountain episodes were often accompanied by lava flows from the flanks of the South-East Crater, with high emission rates in correspondence of the climax of the fire-fountain phases. A detailed descriptions of the eruptive activity is contained in Alparone et al. (2003) and Behncke et al. (2006) and in the papers referenced therein.

\subsection{Features of the erupted products}

Scoria clasts erupted during Strombolian and fire-fountain activity show distinct textural and compositional characteristics, which are respectively summarized in Tables 1 and 2 . As a general observation, samples from both styles of activity exhibit small $(<200 \mu \mathrm{m})$, generally isolated, rounded to sub-rounded vesicles, and larger (from hundreds of microns to $>1 \mathrm{~cm}$ but mostly $>0.5 \mathrm{~mm}$ ), well connected vesicles 

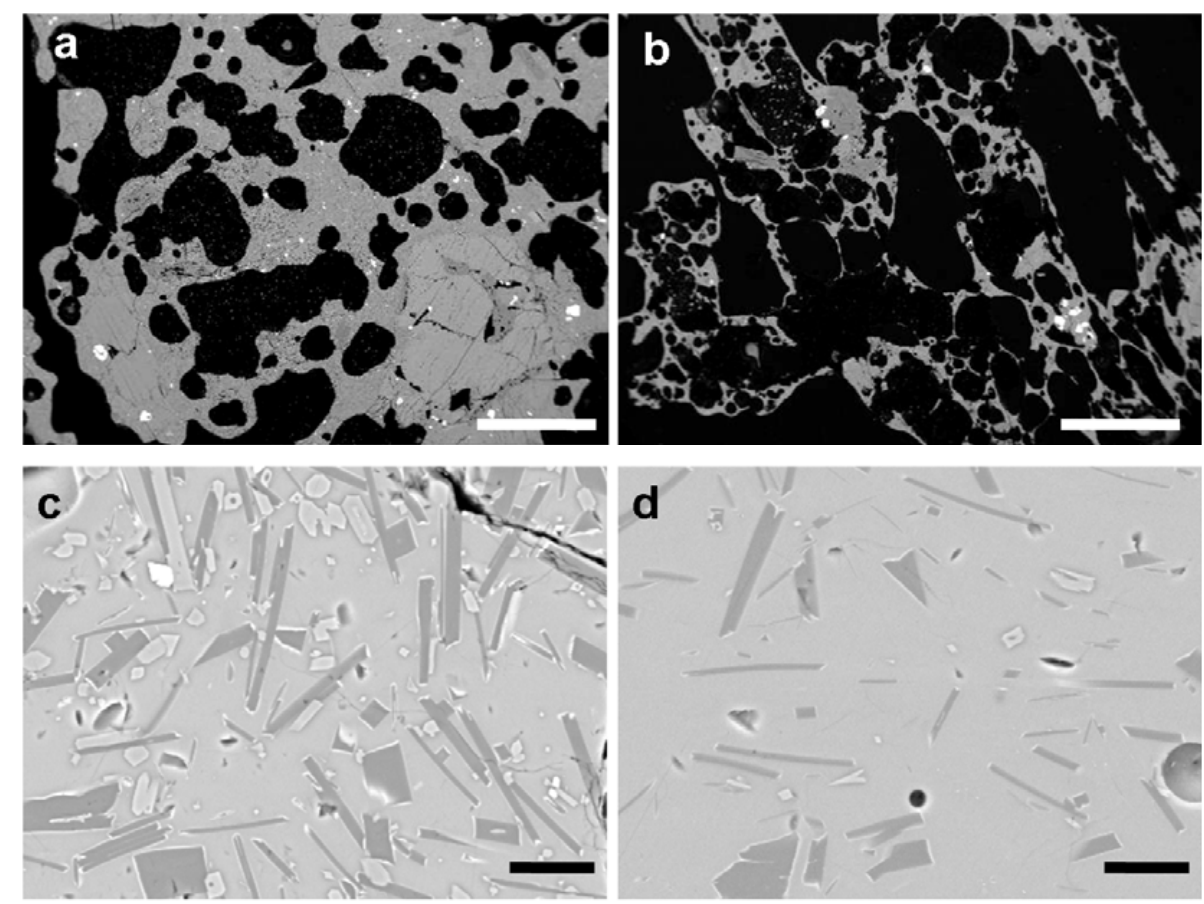

Fig. 2. Backscattered scanning electron images of bulk (top images) and groundmass (bottom images) textures in scoria clasts from Strombolian (a) and (c) and fire-fountain activity (b) and (d) at Mt. Etna in 2000. Black voids are vesicles, white, dark grey and light grey features are crystals, groundmass glass is in intermediate grey. Scale bar is $1 \mathrm{~mm}$ in (a) and (b) and $20 \mu \mathrm{m}$ in (c) and (d).

Table 1. Summary of textural features of scoriae erupted from the explosive activity at Etna in 2000.

\begin{tabular}{|c|c|c|c|c|}
\hline Sample & Type of activity & Vesicularity $^{\mathrm{a}}$ & Microlite crystallinity ${ }^{\mathrm{a}}$ & Tot crystallinity \\
\hline 040300B & Strombolian & 0.66 & 0.36 & 0.58 \\
\hline 040300B1 & Strombolian & 0.64 & 0.30 & 0.59 \\
\hline 160400D & Strombolian & 0.63 & 0.40 & 0.55 \\
\hline $150500 \mathrm{~B}$ & Fire-fountain & 0.80 & 0.12 & 0.39 \\
\hline $150500 \mathrm{Ea}$ & Fire-fountain & 0.72 & 0.17 & 0.39 \\
\hline $150500 \mathrm{~Eb}$ & Fire-fountain & 0.68 & 0.23 & 0.43 \\
\hline 170500 & Fire-fountain & 0.78 & 0.12 & 0.30 \\
\hline
\end{tabular}

${ }^{a}$ Vesicularity and microlite crystallinity from Polacci et al. (2006).

(Fig. 2). Large vesicles are more deformed in products from fire-fountains and may exhibit ellipsoidal to variably elongated shapes (Fig. 2b). Scoriae from fire-fountains display a less crystallized groundmass (vesicle-free microlite content $<\sim 20$ vol\%) (Table 1 and Fig. $2 \mathrm{c}$ and d), and are more vesicular (phenocryst-free vesicularity $0.7-0.8$, Tables 1 and 2 in Polacci et al., 2006) in comparison to products erupted during Strombolian activity (microlite crystallinity in the range $30-40$ vol\%, vesicularity $\sim 0.65$ ). Fire-fountain scoriae also contain a higher number density of small, isolated, vesicles (such vesicles ranging $2-8 \mathrm{~mm}^{-2}$ in Strombolian scoriae and $11-23 \mathrm{~mm}^{-2}$ in fire-fountain scoriae) and in terms of glass chemistry are less compositionally evolved than Strombolian scoria clasts (Polacci et al., 2006). Finally, eruptive temperatures calculated via the glass geothermometer of Pompilio et al. (1998) are up to $30^{\circ} \mathrm{C}$ higher for the fire-fountain than for the Strombolian products (Table 2).

\section{Rheological model and applications}

\subsection{The models}

As mentioned above, the mixture viscosity is calculated by using two recently published models that account for the continuous description of the Newtonian liquid viscosity in the $T$-composition- $\mathrm{H}_{2} \mathrm{O}$ space (Giordano et al., 2008), 
Table 2. Eruptive temperatures and $\mathrm{CaO} / \mathrm{MgO}$ content in products from explosive activity at Etna in 2000.

\begin{tabular}{lcc}
\hline & Strombolian & Fire-fountain \\
\hline$T\left({ }^{\circ} \mathrm{C}\right)$ & & \\
\hline Average & 1091.9 & 1117.6 \\
Minimum & 1080.5 & 1106.8 \\
Maximum & 1103.3 & 1129.8 \\
\hline CaO/MgO $($ wt $\%)$ & \\
\hline Average & 2.29 & 2.13 \\
Minimum & 2.04 & 1.88 \\
Maximum & 2.48 & 2.30 \\
\hline
\end{tabular}

and for the non-Newtonian effects of crystals and applied rate of strain (Costa et al., 2009). The model of Giordano et al. (2008) calculates the Newtonian shear viscosity $\left(\eta_{m}\right)$ of silicate melts as a function of temperature, 10 major oxides, and volatile content (e.g., $\mathrm{H}_{2} \mathrm{O}$ and $\mathrm{F}$ ). The model is calibrated on $\sim 1800$ viscosity measurements on dry and hydrous multi-component melts, and accounts for non-Arrhenian temperature dependence. Since a significant dataset used to calibrate the model refers to basaltic compositions (e.g., Giordano and Dingwell, 2003; Sato, 2005; Giordano et al., 2006; Ishibashi and Sato, 2006), this model is particularly suited for calculating magma viscosity of undersaturated basaltic products. The ability of the model of accurately predicting the viscosity of basaltic melts can be appreciated in Fig. 3.

The non-Newtonian rheology of crystal suspensions are accounted for by the Costa et al. (2009) model. This model computes the relative viscosity $\eta_{r}$ (viscosity of a crystalmelt mixture divided by the viscosity of the melt phase). Compared to previous models (e.g., Einstein-Roscoe, 1952; Costa, 2005; Caricchi et al., 2007), the Costa et al. (2009) model takes into account the strain-rate dependent rheology of liquid+crystal mixtures up to a higher crystal fraction of $\sim 0.80$, ensuring consistency with calculations done via the Einstein-Roscoe equation (Roscoe, 1952) for low to zero crystal contents. Major element glass composition, inferred temperatures, and measured crystal contents were implemented in the above rheological modeling to estimate magma viscosity during the Strombolian and fire-fountain phases of the 2000 eruption at Mt. Etna (Table 2). Temperature ranges of $1080-1103^{\circ} \mathrm{C}$ and of $1106-1129^{\circ} \mathrm{C}$ were respectively taken as representative of the Strombolian and fire-fountain phases of the eruption. These estimates (Table 2) are calculated via a glass geothermometer calibrated on Etnean rocks samples (Pompilio et al., 1998).

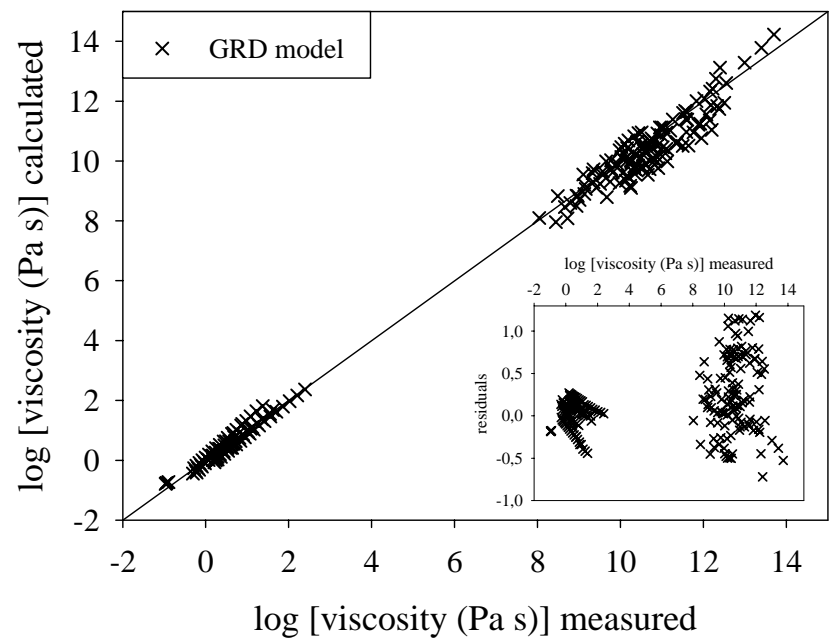

Fig. 3. Calculated vs measured viscosities for $\mathrm{SiO}_{2}$-undersaturated natural melts $\left(\mathrm{SiO}_{2}\right.$ in the $40-50 \mathrm{wt} \%$ range): Witthington et al., 2000, 2001 (basanitic - NIQ -and tephritic compositions); Giordano and Dingwell, 2003a, b (Eifel basanite; Etna trachybasalt; Vesuvius phonotephrite); Dingwell et al., 2004 (Balmuccia peridotite); Bouhifd et al., 2004 (Stein Frenz tephrite and phonotephrite); Sato, 2005; Ishibashi and Sato, 2007; Giordano et al., 2006, 2007, 2008, 2009 (Slapany basanite, Nyiragongo phoidite, Stromboli materials, 1906 Vesuvius eruption tephrite); Villeneuve et al., 2009; Ishibashi, 2009. The calculations are based on the Giordano et al. (2008) (GRD) model and reproduce high temperature (close to eruptive temperature) and low temperature (close to glass transition) data with less than $0.35 \log$ units RMSE (Root Mean Standard Error). Accuracy of the predictions at close to eruptive temperature is significantly higher, with RMSE less than $0.2 \mathrm{log}$ units.

\subsection{Viscosity calculations}

Average crystal contents of 0.57 for the Strombolian phase and 0.37 for the fire-fountain phase, both referred to a vesicle-free magma, were adopted in most calculations. Figure 4 shows the strain-rate dependence of the relative viscosity at varying crystal volume fractions. As shown in Fig. 4a, the relative viscosity of two-phase mixture increases following a sigmoid curve with exponential increase above a critical solid fraction. Variations of crystal content cause orders of magnitude changes in viscosity. The critical crystal volume fraction depends on crystal shape, size distribution and crystal orientation, decreasing with randomness in object orientation and particle shape anisotropy (i.e., equant vs elongated) and increasing with dispersion in object size (Chong, 1971; Lejeune and Richet, 1995; Saar, 2001; Caricchi et al., 2007., 2008; Costa et al., 2009).

As a first order approximation, calculations with the model of Costa et al. (2009) are shown for the simple case of equally sized, mono-distributed spheres. A huge effect on the magmatic mixture viscosity is observed when moving from a crystal volume fraction of 0.37 to 0.57 (Fig. 4b), 

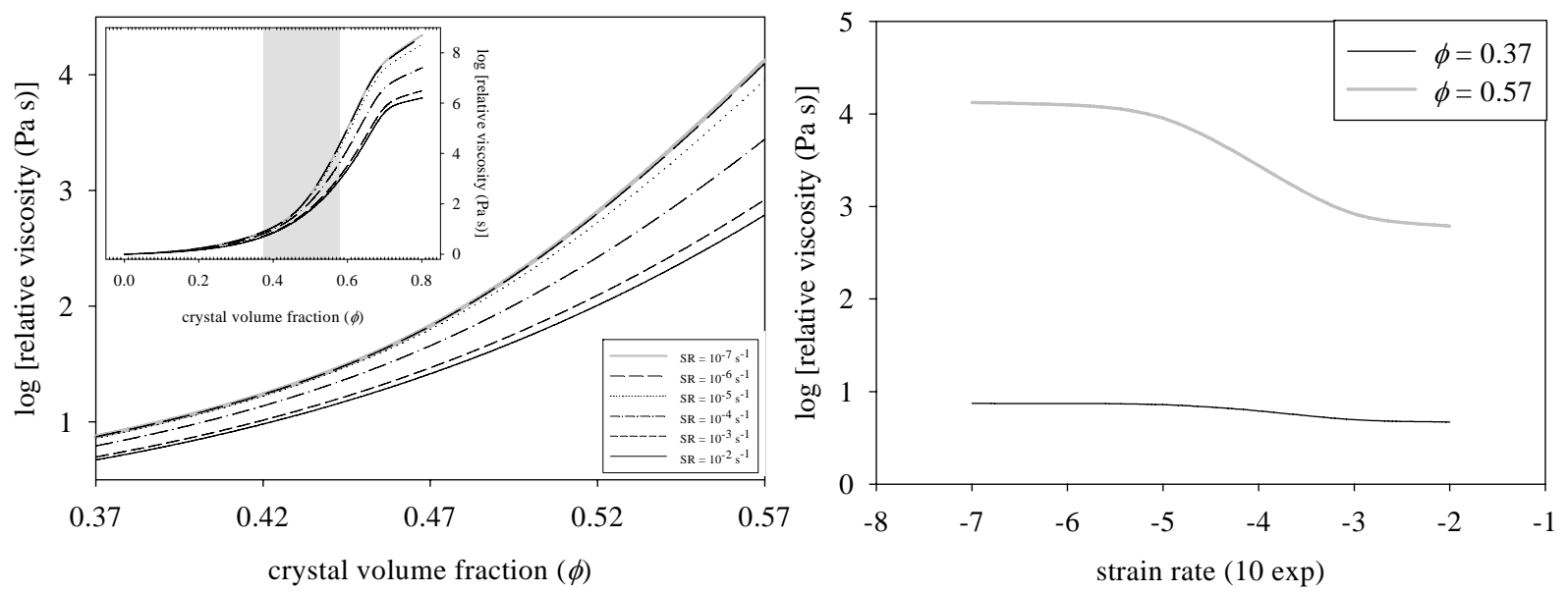

Fig. 4. (a) Relative viscosity as a function of crystal volume fraction at different strain-rates; (b) relative viscosity as a function of strainrate for two crystal volume fractions of 0.37 and 0.57 , adopted for the fire-fountain and the Strombolian phases of the Etna 2000 activity, respectively. Calculations made with the model in Costa et al. (2009).

representative of the two magma types erupted during the fire-fountain and Strombolian phases of the $2000 \mathrm{Mt}$. Etna activity, respectively. This effect is maximum at low strain rates $\left(<10^{-5} \mathrm{~s}^{-1}\right)$ where the rheology is approximately Newtonian, and it is reduced at higher strain-rates where non-Newtonian behaviour becomes substantial for large crystal contents.

Figure 5 shows calculations at constant $\mathrm{H}_{2} \mathrm{O}$ contents of $0.3 \mathrm{wt} \%$ and $0.7 \mathrm{wt} \%$, corresponding to the residual water content in the magma discharged during the Strombolian and fire-fountain phases, respectively (Metrich et al., 2004; Spilliaert et al., 2006). The calculations are shown for two different low and high rates of strain. To consider the effect of crystals on the viscosity of the erupted magmas, the relative viscosity of the Strombolian and fire-fountain products were first calculated using the Costa et al. (2009) model with crystal contents reported above and representative of those in Table 1. Relative viscosities were then multiplied by melt viscosities calculated through the Giordano et al. (2008) model. The plots in Fig. 5 clearly show that the viscosities of the two different crystal-rich and crystal-poor magmas plot in two well distinct fields, with the magma from the Strombolian activity displaying values from 2 to 4 orders of magnitude higher.

\subsection{Application to conduit flow dynamics}

The rheological models described above have been implemented in the Conduit 4 code for the 1-D steady multiphase dynamics of conduit flow (Papale, 2001). With this update, the code embodies non-Newtonian rheology as due to strainrate dependent viscosity of magmatic crystal suspensions as described by the Costa et al. (2009) model. Additionally, the recent model of Giordano et al. (2008) for silicate liquid viscosity as a function of temperature, liquid composition, and dissolved water has been implemented. For any condition in terms of locally-defined silicate liquid composition, dissolved volatiles, temperature, and rate of strain encountered in the flow dynamics calculations, the viscosity of the liquid-crystal magmatic mixture is the one implied by the two rheological models referenced above.

Strictly speaking, the introduction of non-Newtonian rheology requires at least 2-D flow modeling in order to compute the velocity profile and the internal friction forces at any level in the conduit. Our 1-D approach retains instead the simplified assumption of parabolic velocity profile typical of Newtonian fluids, but locally computes an effective viscosity based on non-Newtonian behavior described above. Although 2-D modeling can approximate better the true conditions in the conduit, we still capture the major effect of a change of viscosity at any level during magma flow as a consequence of the high crystal content of magma and the locally computed rate of strain.

For the present purposes, the particles (crystals) dispersed in the liquid magma have been assumed to have a spherical shape, after having verified that elongated shapes with aspect ratio up to 10 involve variations in the calculated mass flow-rate of less than $5 \%$ on a log scale. While the steady flow model can be applied to the long-lasting firefountain phases of the 2000 eruption of Mt. Etna, the highly unsteady character of the Strombolian phases prevents its application. The rheologically updated Conduit 4 code has been therefore applied to the fire-fountain phase first, in order to identify a conduit diameter consistent with the observed mass flow-rates. Besides the mass flow-rate, the eruptive conditions have been constrained by the silicate liquid composition (10 major oxides), magma temperature, total volatiles $\mathrm{H}_{2} \mathrm{O}$ and $\mathrm{CO}_{2}$, and total crystal content assumed to correspond to 0.35 volume fraction (referred to vesiclefree magma). The code then computes a conduit diameter 

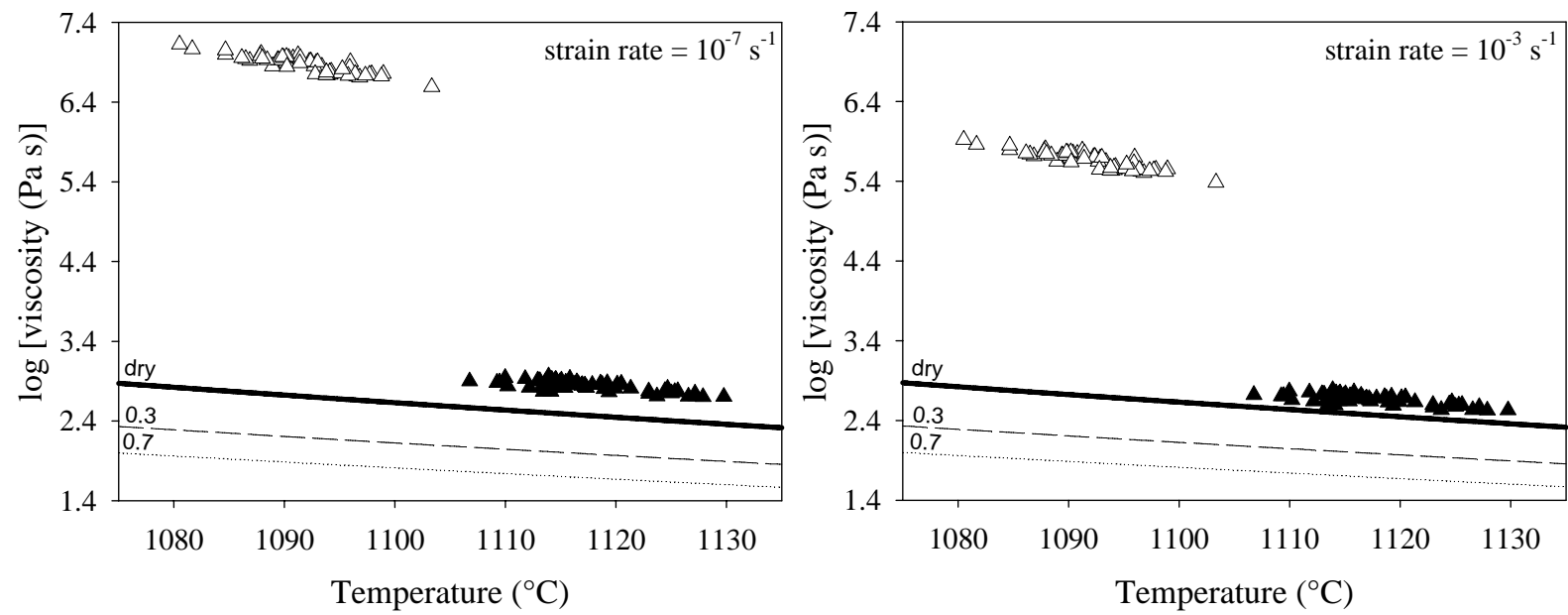

Fig. 5. Calculated liquid-crystal viscosity as a function of temperature for the magmas erupted during the Strombolian (open symbols) and fire-fountain (solid symbols) phases of the 2000 Mt. Etna activity. The calculations assume a crystal volume fraction of 0.37 for the fire-fountain phase and 0.57 for the Strombolian phase (see text and Table 1). The viscosity of pure liquids at anhydrous and dissolved water contents (reported in the figure) of 0.3 and $0.7 \mathrm{wt} \%$, calculated with the GRD model, are also shown as lines in the figure. At the same temperature (in the interval between 1050 and $1150^{\circ} \mathrm{C}$ ) and $\mathrm{H}_{2} \mathrm{O}$ content (dry to $0.7 \mathrm{wt} \%$ ) the average viscosity difference calculated for liquids of composition of the glass matrices of Strombolian and fire-fountain products is about 0.2 logunits. This difference reduces at 0.15 and 0.08 logunits at water content of 2.0 and 4.0 as those adopted in the simulations. This effect would not affect the overall results of the numerical simulations.

Table 3. Input data for the numerical simulations. The composition of a sample from 15 May 2000 (ff150500), has been selected as a typical composition.

\begin{tabular}{llr}
\hline & & ff 150500 \\
\hline conduit length $(\mathrm{m})^{\mathrm{a}}$ & & 1500 \\
pressure at conduit base $(\mathrm{Pa})$ & & $4.5 \times 10^{7}$ \\
magma temperature $(\mathrm{K})$ & & 1390 \\
average crystal density $\left(\mathrm{kg} / \mathrm{m}^{3}\right)$ & & 2800 \\
magma composition $(\mathrm{wt} \%)$ & $\mathrm{SiO}_{2}$ & 48.55 \\
& $\mathrm{TiO}_{2}$ & 2.07 \\
& $\mathrm{Al}_{2} \mathrm{O}_{3}$ & 16.77 \\
& $\mathrm{Fe}_{2} \mathrm{O}_{3}$ & 1.86 \\
& $\mathrm{FeO}$ & 8.00 \\
& $\mathrm{MnO}$ & 0.20 \\
& $\mathrm{MgO}$ & 4.31 \\
& $\mathrm{CaO}$ & 9.08 \\
& $\mathrm{Na} 2 \mathrm{O}$ & 4.14 \\
& $\mathrm{~K}_{2} \mathrm{O}$ & 3.07
\end{tabular}

Water content

$4.0 ; 2.0$

${ }^{\text {a }}$ Vergniolle at al. (2008)

and the corresponding vertical distribution of flow quantities and magma properties corresponding to the assumed mass flow-rate.

A second set of simulations has been performed by assuming this time a conduit diameter consistent with the fire-fountain phase as determined above, and progressively increasing the crystal content up to that of the Strombolian phase. Here the aim is that of evaluating what would be the net effect on the eruption dynamics of just erupting more crystal-rich magmas. Figure 6 shows the set of pressure distributions along the conduit obtained as described above, for crystal contents from 0.35 to 0.59 and water content of $4 \mathrm{wt} \%$ (Table 3). For this set of simulations, the ascending magma is never found to reach the conditions for fragmentation, apart from the most crystal-rich cases, and at a level corresponding to the conduit exit. The pressure is larger than lithostatic everywhere, increasing with decreasing crystal content of the erupted magma. It is worth noting that for the present purposes, we refer to magma fragmentation as the brittle process occurring in a volcanic conduit, not considering fragmentation upon rapid expansion to atmospheric pressure that results in lava spatters or ash production from the top of lava fountains. In this sense, lava fountains belong to the non-fragmented family of eruptions, since the discharged magma emerges from the vent in the form of a liquid continuum. Figure 7 illustrates the effect on mass flow-rate of the discharge of progressively crystal-richer magma. Comparing the conditions at the lowest and highest employed crystal contents, representative of the fire-fountain and Strombolian phases, respectively, reveals that such an increase of the crystal content at equally other conditions produces a decrease of the mass flow-rate by one order of magnitude. If the total water content is decreased from 4 to $2 \mathrm{wt} \%$ (Fig. 7) when the crystal content is increased, the decrease in mass flow-rate is even more dramatic. 


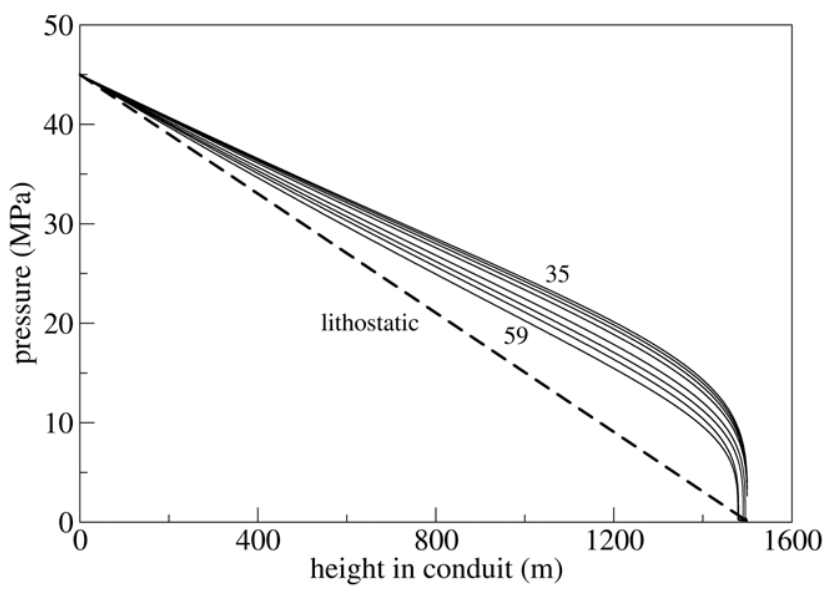

Fig. 6. Calculated pressure distribution along the conduit for magmas from 35 to $59 \mathrm{vol} \%$ of crystals relative to the liquid-crystal phase. Assumed total water content: $4 \mathrm{wt} \%$. All other conditions reported in Table 3. The calculations are performed with the Conduit4 code (Papale, 2001), assuming a fixed conduit diameter of $4.5 \mathrm{~m}$, corresponding to the conduit diameter required (from the simulations) to produce an observed mass flow-rate of $2.5 \times 10^{5} \mathrm{~kg} / \mathrm{s}$ for the fire-fountain eruption phase with $35 \mathrm{vol} \%$ crystals.

Figures 6 and 7 also show that small variations of the crystal content in the erupted magma have an effect which is comparably small if the crystal content is relatively small, but it can be substantial if the crystal content is sufficiently high. At the large crystal contents comparable with that of the Strombolian phases at Mt. Etna, small variations of the crystal content are expected to result in large fluctuations of the mass flow-rate (Fig. 7), suggesting a tendency towards unsteady eruption dynamics.

\section{Discussion and conclusions}

The analysis and modelling carried out in this paper demonstrates that the phases characterized by Strombolian and firefountain activity during the 2000 summit eruption cycle at Mt. Etna were characterized by the emission of magma having effective viscosity of the multiphase mixture differing by orders of magnitude. Higher viscosity was associated with the Strombolian phases as a consequence of larger crystal content of magma trespassing a critical value at around $50 \mathrm{vol} \%$, above which the slope of the viscosity vs. crystal content curve rapidly increases. Numerical modelling of steady magma flow performed here suggests that at such large crystal contents small heterogeneities in the solid particles carried by the magma may imply large fluctuations of the flow conditions, effectively hampering the onset of steady flow conditions. We propose here that the large crystal content $>50 \mathrm{vol} \%$ of the Strombolian eruption phases represented a rheological barrier for the onset of a substeady fire-fountain phase like those characterizing instead

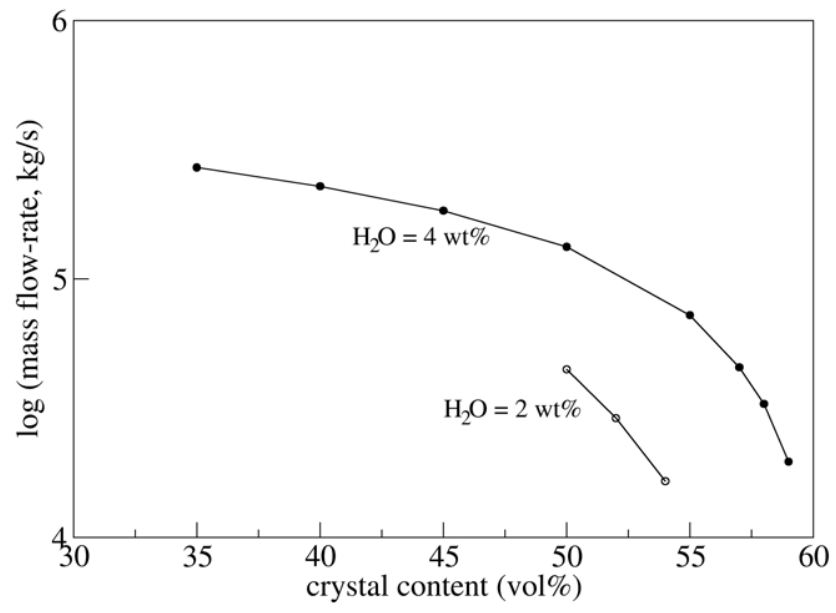

Fig. 7. Calculated mass flow-rate as a function of the crystal content, for the simulations in Fig. 6 plus a few others with assumed total water content of $2 \mathrm{wt} \%$.

the discharge of magma with 30-40 vol\% crystal content. According to this view, when the deep forces sustaining efficient magma discharge waned, the magma residing at shallow levels in the conduit had sufficient time to crystallize under degassed and cooling conditions. Addition of about $20 \mathrm{vol} \%$ crystals to the original magma resulted in 2 to 3 orders of magnitude increase in viscosity, and in the formation of a plug of scarcely mobile magma on top of the magmatic column. Remobilization occurred then through a sequence of strongly unsteady Strombolian pulses until the viscous plug was eliminated and a new fire-fountain phase discharging less crystal-rich and less viscous magma took place. The numerical simulations presented in Figs. 6 and 7 provide also a physical interpretation for the association between firefountaining and accompanying lava flows, often observed during the eruptive sequence. In fact, steady magma discharge turns out to be associated with large overpressure in the volcanic conduits (Fig. 6), with maxima around $10 \mathrm{MPa}$ in correspondence of the upper portion of the conduit. Such a conduit region corresponds to the cone of the South-East Crater, mainly formed by the accumulation of tephra during the last 30 years of activity of Mt. Etna and therefore characterized by low cohesion and mechanical strength. It is therefore expected that during the fire-fountain phases of the eruption dyke intrusion occurs at the level of the cone due to the favourable combination of highest magmatic overpressure and lowest mechanical resistence of surrounding rocks. Dyke intrusion at this shallow level would therefore cause lava flows to emerge from the flanks of the South-East Crater during the fire-fountain phases of the eruption, as it was in fact repeatedly observed (Behncke et al., 2006). The further observation from Behncke et al. (2006) that the peaks in mass discharge rate during the fire-fountain phases were accompanied by an increase in the output rate of the lava flows 
emerging from the flanks of the tephra cone is also perfectly consistent with our results at Figs. 6 and 7, that show peak overpressure at shallow levels in coincidence of the highest simulated mass flow-rates.

Acknowledgements. D. Giordano acknowledges support from the Subdirección General de Formación e Incorporación de Investigadores - Programa Ramón y Cajal (RYC-MICINN) del Ministerio de Ciencia e Innovación - Dirección General de Investigación y Gestión del Plan Nacional de I+D+i (DGI) de España. Also acknowledged is the support from the FIRB AIRPLANE project 2007-2010 and the Experimental Volcanology and Petrology Laboratory (Laboratorio di Vulcanologia e Petrologia Sperimentale) of the Geological Sciences Department of the Third University of Rome. This work has also been developed in the frame of the project INGV-DPC 2007-09 V4 - Flank. O. Melnik and Y. Lavallée are acknowledged for their constructive reviews.

Edited by: D. B. Dingwell

\section{References}

Allard, P., Burton, M., and Murè, F. : Spectroscopic evidence for a lava fountain driven by previously accumulated magmatic gas, Nature, 433, 407-410, 2005.

Alparone, S., Andronico, D., Lodato, L., and Sgroi, T.: Relationship between tremor and volcanic activity during the Southeast Crater eruption on Mt. Etna in early 2000, J. Geophys. Res., 108, 22412253, 2003.

Behncke, B., Neri, M., Pecora, E., and Zanon, V.: The exceptional activity and growth of the Sotheast crater, Mt. Etna (Italy), between 1996 and 2001, B. Volcanol., 69, 149-173, 2006.

Bouhifd, M. A., Richet, P., Besson, P., Roskosz, M., and Ingrin, J.: Redox state, microstructure and viscosity of a partially crystallized basalt melt, Earth Planet. Sc. Lett., 218, 31-44, 2004

Bourgue, E. and Richet, P.: The effects of dissolved $\mathrm{CO}_{2}$ on the density and viscosity of silicate melts: a preliminary study, Earth Planet. Sc. Lett., 193, 57-68, 2001.

Branca, S. and Del Carlo, P.: Eruptions of Mt. Etna during the past 3200 years: a revised compilation integrating the Historical and stratigraphic records, in: Bonaccorso, A., Calvari, S., Coltelli, M., Del Negro, C., and Falsaperla, S., Mt. Etna: Volcano Laboratory, AGU Geophys. Monogr. Ser., 143, 1-27, 2004.

Coltelli, M., Del Carlo, P., and Vezzoli, L.: Stratigraphic constrains for explosive activity in the past $100 \mathrm{ka}$ at Etna volcano, Italy, Int. J. Earth Sci., 89, 665-677, 2004.

Caricchi, L., Burlini, L., Ulmer, P., Gerya, T., Vassalli, M., and Papale, P.: Non-Newtonian rheology of crystal-bearing magmas and implications for magma ascent dynamics, Earth Planet. Sc. Lett., 264, 402-419, doi:10.1036/j.eps12007.09.032, 2007.

Caricchi, L., Giordano, D., Burlini, L., Ulmer, P., and Romano, C.: Rheological properties of magma from the 1538 eruption of Monte Nuovo (Phlegrean Fields, Italy): an experimental study, Chem. Geol., 256, 157-170, 2008.

Chong, J. S., Christiansen, E. B., and Baer, A. D.: Rheology of concentrated suspensions, J. Appl. Polym. Sci., 15, 2007-2021, 1971.
Costa, A.: Viscosity of high crystal content melts: dependence on solid fraction, Geophys. Res. Lett., 32, L22308, doi:10.1029/2005GL024303, 2005.

Costa, A., Caricchi, L., and Bagdassarov, N.: A model for the rheology of particle-bearing suspensions and partially molten rocks, Geochem. Geophy. Geosy., 10, Q03010, doi:10.1029/2008GC002138, 2009.

Dingwell, D. B., Courtial, P., Giordano, D., and Nichols, A. R. L.: Viscosity of peridotite liquid, Earth Planet. Sc. Lett., 226, 127138, 2004.

Giordano, D. and Dingwell, D. B.: Viscosity of hydrous Etna basalt: implications for Plinian-style basaltic eruptions, B. Volcanol., 65, 8-14, 2003a.

Giordano, D. and Dingwell, D. B.: Erratum to: Non-Arrhenian multicomponent melt viscosity: a model, Earth Planet. Sc. Lett., 208, 337-349, 2003b.

Giordano, D., Mangiacapra, A., Potuzak, M., Russel, J. K., Romano, C., Dingwell, D. B., and Di Muro, A.: An expanded nonArrhenian model for silicate melt viscosity: a treatment for metaluminous, peraluminous and peralkaline liquids, Chem. Geol., 229, 42-56, 2006.

Giordano, D., Polacci, M., Longo, A., Papale, P., Dingwell, D. B., Boschi, E., and Kasereka, M.: Thermorheological magma control on the impact of highly fluid lava flows at Mt. Nyiragongo, Geophys. Res. Lett., 34, L06301, doi:10.1029/2006GL028459, 2007.

Giordano, D., Russell, J. K., and Dingwell, D. B.: Viscosity of magmatic liquids: a model, Earth Planet. Sc. Lett., 271, 123-134, 2008.

Giordano, D., Ardia, P., Romano, C., Dingwell, D. B., Di Muro, A., Schmidt, M. W., Mangiacapra, A., and Hess, K.-U.: The rheological evolution of alkaline Vesuvius magmas and comparison with alkaline series from the Phlegrean Fields, Etna, Stromboli and Teide, Geochim. Cosmochim. Ac., 73, 6613-6630, 2009.

Ishibashi, H. and Sato, H.: Viscosity measurements of subliquidus magmas: Alkali olivine basalt from the Higashi-Matsuura district, Southwest Japan, J. Volcanol. Geoth. Res., 160, 223-238, 2007

Ishibashi, H.: Non-Newtonian behavior of plagioclase-bearing basaltic magma: Subliquidus viscosity measurement of the 1707 basalt of Fuji volcano, Japan, J. Volcanol. Geoth. Res., 181, 7888, 2009.

Lejeune, A. M. and Richet, P.: Rheology of crystal-bearing silicate melts: an experimental study at high viscosities, J. Geophys. Res., 100(B3), 4215-4229, 1995.

Métrich, N., Allard, P., Spilliaert, N., Andronico, D., and Burton, M.: 2001 flank eruption of the alkali- and volatile-rich primitive basalt responsible for Mt. Etna's evolution in the last three decades, Earth Planet. Sc. Lett., 228, 1-17, 2004.

Papale, P.: The dynamics of magma flow in volcanic conduits with variable fragmentation efficiency and non-equilibrium pumice degassing, J. Geophys. Res., 106, 11043-11065, 2001.

Pinkerton, H. and Stevenson, R. J.: Methods of determining the rheological properties of magmas at sub-liquidus temperatures, J. Volcanol. Geotherm. Res., 53, 47-66, 1992.

Pinkerton, H. and Norton, G.: Rheological properties of basaltic lavas at sub-liquidus temperatures: laboratory and field measurements on lavas from Mt. Etna, J. Volcanol. Geotherm. Res., 68, 307-323, 1995. 
Polacci, M., Corsaro, R. A., and Andronico, D.: Coupled textural and compositional characterization of basaltic scoria: Insights into the transitino from Strombolian to fire fountain activity at Mt. Etna, Italy, Geology, 34, 201-204, 2006

Pompilio, M., Trigila, R., and Zanon, V.: Melting experiments on Mt. Etna lavas, I. The calibration of an empirical geothermometer to estimate the eruptive temperature, Acta Vulcanol., 10, 67-75, 1998 .

Roscoe, R.: The viscosity of suspensions of rigid spheres, J. Appl. Sci., 3, 267-269, 1952.

Ryerson, F. J., Weed, H. C., and Piwinskii, A. J.: Rheology of Subliquidus Magmas, 1. Picritic Compositions, J. Geophys. Res., 93, 3421-3436, 1988.

Saar, M. O., Manga, M., Cashman, K. V., and Fremouw, S.: Numerical models of the onset of yield strength in crystal-melt suspensions, Earth Planet. Sc. Lett., 187, 367-379, 2001.

Sato, H.: Viscosity measurement of subliquidus magmas: 1707 basalt of Fuji volcano, J. Miner. Petrol. Sci., 100, 133-142, 2005.
Shaw, H. R.: Rheology of basalt in the melting range, J. Petrol., 10, 510-535, 1969.

Spilliaert, N., Allard, P., Métrich, N., and Sobolev, A. V.: Melt inclusion record of the conditions of ascent, degassing, and extrusion of volatile-rich alkali basalt during the powerful 2002 flank eruption of Mt. Etna (Italy), J. Geophys. Res., 111, B04203, doi:10.1029/2005JB003934, 2006.

Villeneuve, N., Neuville, D. R., Boivin, P., Bachèlery, P., and Richet, P.: Magma crystallization and viscosity: A study of molten basalts from the Piton de la Fournaise volcano (La Réunion island), Chem. Geol., 256, 242-251, 2008.

Walsh, S. D. C. and Saar, M. O.: Numerical models of stiffness and yield stress growth in crystal-melt suspensions, Earth Planet. Sc. Lett., 267, 32-44, 2008.

Whittington, A., Richet, P., and Holtz, F.: Water and the viscosity of depolymerised aluminosilicate melts, Geochim. Cosmochim. Ac., 64, 3725-3736, 2000.

Whittington, A., Richet, P., Linard, Y., and Holtz, F.: The viscosity of hydrous phonolites and trachytes, Chem. Geol., 174, 209-223, 2001. 